\title{
Defective Expression of T Cell-associated Glycoprotein in Severe Combined Immunodeficiency
}

\author{
Lawrence K. L. Jung, Shu Man Fu, Toshiro Hara, Neena Kapoor, and Robert A. Good \\ Cancer Research Program, Oklahoma Medical Research Foundation; and Department of Pediatrics, Oklahoma Children's \\ Memorial Hospital, Oklahoma City, Oklahoma 73104
}

\begin{abstract}
A $T$ cell surface membrane-associated glycoprotein, Tp40 (40,000 mol wt), also designated as CD-7, was not expressed by the $T$ cells of a patient with severe combined immunodeficiency. In addition to this abnormality, $T$ cell proliferative responses to mitogens were defective and the IL-2 receptor expression was deficient on the patient's $T$ lymphocytes. However, his $T$ cells were found to provide help for the differentiation of normal $B$ cells to Ig-secreting cells. Abundant circulating B cells were detected. These B cells proliferated normally in the presence of anti- $\mu$ antibodies and $B$ cell growth factors, but did not differentiate into antibody-secreting cells when provided with the help of normal $T$ cells. In addition, his activated $B$ cells did not proliferate to IL-2 even though IL-2 receptors were expressed. A successful allogeneic histocompatible bone marrow transplantation resulting in $T$ cell engraftment corrected both the $T$ and $B$ cell immunodeficiencies. These findings support the hypothesis that the Tp40 deficiency present in this patient is related to a defect of the $T$ cell precursors, and that $T p 40$ plays important roles not only essential to $T$ cell interactions but also to certain aspects of T-B cell interaction during the early lymphoid development.
\end{abstract}

\section{Introduction}

Severe combined immunodeficiency (SCID) ${ }^{1}$ is a heterogenous group of diseases $(1,2)$. Certain variants of SCID, such as those associated with adenosine deaminase deficiency $(3,4)$ or the bare lymphocyte syndrome (5-7), have been shown to have identifiable underlying pathogenetic mechanisms. However, the pathologic basis for most cases of SCID are obscure and have

A part of this investigation was published as an abstract (1985. Clin. Res. 33:557A) and was presented at the National Meeting of the Association of American Physicians/American Society for Clinical Investigation/American Federation for Clinical Research, in Washington, D. C., 1985.

Address correspondence to Dr. Jung, Oklahoma Medical Research Foundation. The present address of Dr. Kapoor and Dr. Good is the All Children's Hospital, St. Petersburg, FL 33701-4899.

Received for publication 15 May 1985 and in revised form 7 November 1985.

1. Abbreviations used in this paper: BCGF, B cell growth factor; BMT, bone marrow transplantation; Con A, concanavalin A; FITC, fluorescein isothiocyanate; GVHD, graft-vs.-host disease; IL-2, interleukin 2; mAb, monoclonal antibody; MLC, mixed leukocyte cultures; $\mathrm{M} \phi \mathrm{S}$, macrophage factor; PFC, plaque-forming cell; PHA, phytohemagglutinin; PWM, pokeweed mitogen; RBC(s), erythrocyte; rIL-2, recombinant IL-2; SCID, severe combined immunodeficiency; TdR, thymidine.

J. Clin. Invest.

(c) The American Society for Clinical Investigation, Inc.

0021-9738/86/03/0940/07 \$1.00

Volume 77, March 1986, 940-946 been variously attributed to stem cell defects (8) or deficiencies of the thymic influence $(9,10)$. Recent development of monoclonal reagents has led to identification of deficiencies of helper $T$ cells in certain cases (11-13). However, selective deficiency of a major $\mathrm{T}$ cell-associated marker has not yet been reported. In this report we present a case of SCID in which the T cells have been shown to be selectively deficient in a $\mathrm{T}$ cell-associated glycoprotein, Tp40 (14). The abnormality was associated with defective $T$ cell proliferation and with defects in $B$ cell differentiation. After a successful bone marrow transplantation (BMT) from a histocompatible sibling, $T$ cell reconstitution was accompanied by the appearance of $\mathrm{Tp} 40^{+}$lymphocytes and correction of both $\mathrm{T}$ and B cell defects. These findings suggest that Tp40 plays an important role in the ontogeny of $T$ and $B$ cell functions and that its absence may have been responsible for the SCID in this patient.

\section{Methods}

Patient. A 5-mo-old Mexican male was admitted to Oklahoma Children's Memorial Hospital with a history of failure to thrive, candidiasis, protracted diarrhea, and upper respiratory tract infection since the age of 2 mo. Immunological workup revealed the absolute lymphocyte count to be $10,000 / \mathrm{mm}^{3}$. His T cell numbers were greatly diminished. $5.2 \%$ of the lymphoid cells expressed OKT $11,2.7 \% \mathrm{OKT}^{+}, 6.1 \% \mathrm{OKT}^{+}$, and $0.5 \% \mathrm{OKT}^{+}$surface markers. These data were obtained with OKT Series antibodies in the Clinical Laboratory at the Oklahoma Children's Memorial Hospital with a Spectrum III instrument (Ortho Diagnostic Systems, Inc., Westwood, MA). As shown in Fig. 1, the majority of the T cells isolated by a sheep erythrocyte rosette method in our laboratory were stained with our own anti-T3 antibody, 235(15). The difference between our results and those obtained in the clinical laboratory might be due to different antibodies and instrumentation. Because of limited blood samples available, the difference was not pursued further. The majority of circulating lymphocytes had surface IgD (79.1\%) and/or $\operatorname{IgM}(77.5 \%)$.

The child had low levels of circulating immunoglobulin: IgA 15.1 $\mathrm{mg} / \mathrm{dl}$, IgG $55.9 \mathrm{mg} / \mathrm{dl}$, and IgM $59.2 \mathrm{mg} / \mathrm{dl}$. Serum thymulin (FTS) was undetected when his serum was diluted to 1:4. Mitogenic responses to phytohemagglutinin (PHA), concanavalin A (Con A), and pokeweed mitogen (PWM) were $1,435 \mathrm{cpm}$ (normal $>75,000 \mathrm{cpm}$ ), $529 \mathrm{cpm}$ (normal $>40,000 \mathrm{cpm}$ ), and 1,381 cpm (normal $>10,000 \mathrm{cpm}$ ), respectively. Because there was a functional deficiency of both $\mathrm{T}$ and $\mathrm{B}$ lymphocytes, a diagnosis of SCID was made. Adenosine deaminase levels in erythrocytes (RBCs) were normal. There was no family history of early infant deaths or immunodeficiency.

A 15-yr-old female sibling was shown to be HLA compatible, nonreactive in mixed leukocyte cultures (MLC), and $A B O$ matched with the patient. A marrow transplantation was performed without any preparation of the patient. Bone marrow cells from the donor in a dose of $4.79 \times 10^{8}$ nucleated cells $/ \mathrm{kg}$ were infused. Within $2 \mathrm{wk}$ after the transplant, the $T$ cell numbers increased, as revealed by surface marker analysis. During this period, the child developed a skin rash, had profuse diarrhea, and a diagnosis of graft-vs.-host disease (GVHD) was made. The patient was treated with $1 \mathrm{mg} / \mathrm{kg}$ of methylprednisolone for $3 \mathrm{wk}$ and the GVHD completely resolved. The child was discharged from the Bone Marrow 
Transplantation Unit 2 mo after the marrow transplantation and has remained in good clinical condition since discharge.

7 mo after BMT, B cell function was demonstrated. Isoagglutinins were present. Serum immunoglobulin determination, 2 mo after the discontinuation of intravenous gammaglobulin therapy, revealed IgA, $8.5 \mathrm{mg} / \mathrm{dl} ; \mathrm{IgM}, 67 \mathrm{mg} / \mathrm{dl}$; and IgG, $860 \mathrm{mg} / \mathrm{dl}$. T cell reconstitution was demonstrated by the lymphoproliferative responses to PHA $(90,000 \mathrm{cpm})$, Con A (42,000 cpm), and PWM (13,000 cpm). Karyotypic analyses of bone marrow cells also confirmed the establishment of a donor marrow graft. Circulating T cells were of donor origin while B cells were of host type.

Cell preparation. Peripheral blood mononuclear cells from the patient or control subjects were isolated on Ficoll-Hypaque density gradient centrifugation. After monocyte depletion by adherence to plastic, the mononuclear cells were separated into $T$ and non- $T$ cells by rosetting techniques using neuraminidase-treated sheep erythrocytes as described (16).

Monoclonal antibody ( $\mathrm{mAb}$ ) production. mAb 69.3.4 was produced in a fusion between SP2/0 tumor cells and splenocytes of a $\mathrm{BC}_{3} \mathrm{~F}_{1}$ female mouse previously immunized with $\mathrm{PHA}$-activated human $\mathrm{T}$ cells. $\mathrm{Hy}-$ bridoma supernatants were screened for their specific binding on $\mathrm{T}$ cells. This hybridoma was cloned twice on soft agar. Details of these procedures have been described previously (17). mAb $3 \mathrm{Al}$ was kindly provided by Dr. B. Haynes, Duke University School of Medicine, Durham, NC.

Lymphocyte proliferation assay. $2 \times 10^{4}$ or $10^{5}$ lymphocytes in 0.2 $\mathrm{ml}$ of medium were stimulated in microtiter wells with PHA-P (Difco Laboratories Inc., Detroit, MI), PWM, or Con A (Gibco, Grand Island, NY), as described previously (18). B cell proliferation assays were performed as described (19).

Reverse plaque assay. Reverse plaque assays for Ig secretion were performed as described (19).

Immunofluorescence studies. The presence of $\mathrm{Tp} 40$ on $\mathrm{T}$ cells was analyzed using fluorescent microscopy or an Epics $\mathrm{V}$ flow cytometer (Coulter Electronics Inc., Hialeah, FL). Two-color fluorescence microscopy was carried out by staining $\mathrm{T}$ cells with $69.3 .4 \mathrm{mAb}$ conjugated with rhodamine and counterstained with biotinated AT-1 (anti-IL-2 receptor) and fluoresceinated avidin. Details of these methods have been described $(18,19)$.

Immune rosette. Human RBCs collected in Alsever's solution were washed thoroughly in saline. Equal volumes of packed red cells and goat anti-mouse $\mathrm{Ig}(1 \mathrm{mg} / \mathrm{ml})$ were mixed and then suspended in saline at red cell concentration of $20 \% \mathrm{vol} / \mathrm{vol}$. Equal volumes of a $0.006 \%$ (wt/ vol) $\mathrm{CrCl}_{3}$ solution were added dropwise to the $\mathrm{RBC} /$ goat anti-mouse Ig suspension, which was gently vortexed. After incubation for $1 \mathrm{~h}$ at $30^{\circ} \mathrm{C}$, the conjugated red cells were washed thoroughly with RPMI-1640 and resuspended at $5 \% \mathrm{vol} / \mathrm{vol}$ for use.

$10^{7} / \mathrm{ml}$ of lymphoid cells were incubated with an equal volume of hybridoma supernatant for $30 \mathrm{~min}$ at $4^{\circ} \mathrm{C}$. After washing, the lymphoid cells were resuspended to twice the original volume. Antibody-coated $\mathrm{RBCs}$ were then added to the lymphoid cell suspension at a final concentration of $2 \%$. The cell mixture was centrifuged at $1,000 \mathrm{rpm}$ for 5 min and the pellet incubated at $4^{\circ} \mathrm{C}$ for $30 \mathrm{~min}$. The cell pellet was then resuspended gently and rosetting cells were separated from nonrosetting cells by Ficoll-Hypaque density gradient sedimentation. Residual red cells were lysed with buffered $\left(\mathrm{NH}_{4}\right) \mathrm{Cl}$ solution.

Cytokine preparations. Recombinant interleukin 2 (rIL-2) was purchased from Genzyme (Boston, MA). Macrophage factor $(\mathbf{M} \phi \mathbf{S})$ was produced in our laboratory according to the procedures of Finelt and Hoffmann (20) with minor modifications. $5 \times 10^{6}$ mononuclear cells in $1 \mathrm{ml}$ RPMI-1640 containing $20 \%$ fetal calf serum and $2 \mathrm{mM}$ glutamine were incubated at $37^{\circ} \mathrm{C}$ in tissue culture dishes (Falcon 3001, BectonDickinson \& Co., Oxnard, CA) for $1 \mathrm{~h}$. Nonadherent cells were then washed off and the remaining cells incubated in serum-free Mischell Dutton medium with $10 \mu \mathrm{g} / \mathrm{ml}$ lipopolysaccharide (Escherichia coli type 055:B5, Difco Laboratories, Inc.) for $24 \mathrm{~h}$ at $37^{\circ} \mathrm{C}$ in $5 \% \mathrm{CO}_{2}$. The supernatant was harvested, filtered through a $0.45-\mu \mathrm{m}$ filter, and stored at $-20^{\circ} \mathrm{C}$. Conditioned media containing $B$ cell stimulatory factors were produced as described (19). Partially purified B cell growth factor (BCGF) was a kind gift of Dr. A. Maizel (M.D. Anderson Cancer Center, Houston, TX).

\section{Results}

Characterization of $\mathrm{mAb}$ 69.3.4. $\mathrm{mAb}^{69.3 .4}$, an $\mathrm{IgG}_{1}$ antibody, stained $60-80 \%$ of isolated $\mathrm{T}$ cells. It also stained thymocytes and leukemic $\mathrm{T}$ cell lines. It did not stain B cells, granulocytes, monocytes, erythrocytes or platelets. By immunoprecipitation, a 40,000-mol-wt polypeptide was identified as its reactive antigen. $\mathrm{mAb}$ 69.3.4 was found to react with a protein similar to that precipitated by mAb 3A1 (21). Sequential immunoprecipitations were then carried out. $\mathrm{mAb}$ 69.3.4 showed no precipitate with a $\mathrm{T}$ cell lysate that had been first reacted with mAb $3 \mathrm{~A} 1$ plus Sepharose 4B-linked goat anti-mouse Ig antibodies. Thus, mAb 69.3.4 was reactive with the same molecule identified by $\mathrm{mAb}$ $3 \mathrm{~A} 1$. This molecule, which has been shown to be a glycoprotein (22), has been designated as CD-7 by the First International Workshop on Human Leucocyte Differentiation Antigens (14).

Absence of Tp40 on SCID T cells. Although only a few $\mathrm{T}$ cells were present in the blood of our patient with SCID, the T cells present stained for T3, T4, T8 and T11. Despite the presence of these mature $T$ cell markers, the isolated $T$ cells from the patient failed to proliferate when stimulated with $\mathrm{T}$ cell mitogens and alloantigens. Additional $\mathrm{mAb}$ were used to further study these T cells. The patient's T cells expressed HLA antigens and the LFA-1 antigen (23). However, his isolated T cells did not stain with mAb 69.3.4 (Table $I$ and Fig. $1 B$ ) in three separate experiments. By contrast, activated $T$ cells from normal individuals regularly stained strongly and numerously with the 69.3.4 antibody (Table I). Further efforts to activate the patient's T cells did not significantly increase the numbers of $\mathrm{Tp} 40^{+}$cells. As an additional control, $\mathrm{T}$ cells from five cord blood samples were studied, and each was shown to contain $\mathrm{Tp} 40^{+} \mathrm{T}$ lymphocytes, which showed staining intensity, and numbers similar to those present in the blood of adults.

After BMT, the patient's T cell numbers gradually increased.

Table I. Absence of Tp40 on T Cells of Our SCID Patient and Its Expression after BMT as Analyzed by Immunofluorescence

\begin{tabular}{|c|c|c|}
\hline & Resting $\mathrm{T}$ cells & PHA-activated T cells \\
\hline & $\%$ & $\%$ \\
\hline \multicolumn{3}{|l|}{ Patient } \\
\hline Pre BMT & 0 & $<1$ \\
\hline \multicolumn{3}{|l|}{ Post BMT } \\
\hline $2 \mathrm{wk}$ & Not done & 27.9 \\
\hline 7 wk & 18.7 & 32.0 \\
\hline $16 \mathrm{wk}$ & 41.7 & Not done \\
\hline $22 \mathrm{wk}$ & 60.0 & Not done \\
\hline \multicolumn{3}{|l|}{ Family members } \\
\hline Father & 76.5 & $>95$ \\
\hline Mother & 70.6 & $>95$ \\
\hline Sister (donor) & 81.1 & $>95$ \\
\hline \multirow[t]{2}{*}{ Controls (average of five) } & 77.7 & 88.3 \\
\hline & (range 69.4-95.8) & (range 79.3-99.8) \\
\hline
\end{tabular}

Lymphocytes isolated by an $\mathrm{E}$ rosette separation technique were first incubated with $\mathrm{mAb}$ 69.3.4 and then stained with fluorescein isothiocyanate (FITC) goat anti-mouse Ig. After thorough washings, cells were analyzed on an Epics V flow fluorocytometer; 2,000-5,000 cells were analyzed. 


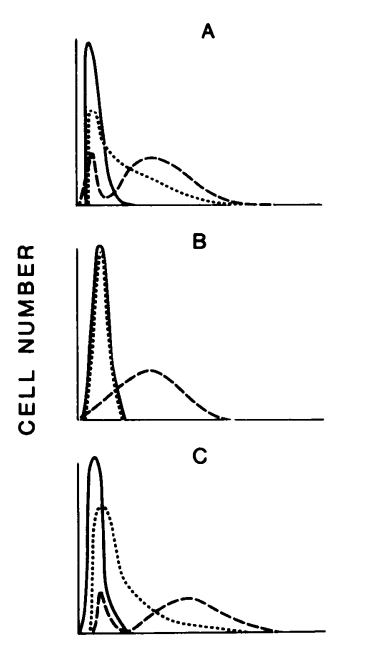

FLUORESCENCE INTENSITY
Figure 1. Cytofluorometric analysis of $T$ cell-associated antigens on sheep erythrocyte rosettes forming cells from $(A)$ control, $(B)$ SCID patient before BMT, and $(C)$ SCID patient after BMT: (-), control; (-- -), T3; and (--..-), Tp40. The fluorescence intensity is expressed on a linear scale.
22 wk posttransplantation, $60 \%$ of the $T$ cells stained for $T p 40$ (Table I and Fig. $1 C$ ) and were shown to be of donor origin with XX chromosomes.

Both parents and the bone marrow donor (sister) were studied with respect to the expression of Tp40. Normal numbers of $\mathrm{Tp} 40^{+}$cells were detected in the blood preparations of each of these family members. The staining intensities of the $T$ cells of these family members were indistinguishable from those of normals.

A brief survey of various immunodeficiency states showed that Tp40 deficiency was not present in lymphocytes of patients with X-linked agammaglobulinemia (three cases), Wiskott-Aldrich syndrome (three cases), or common variable hypogammaglobulinemia (six cases). T cells from two other cases of SCID were examined and $\mathrm{Tp} 40$ was detected in an expected proportion of isolated $\mathrm{T}$ cells from these patients.

Defective $T$ cell proliferative responses and lack of response to cytokines. The functional capacities of the Tp40-deficient $\mathrm{T}$ cells were studied in our patient. His isolated peripheral blood mononuclear cells did not respond with significant proliferations to any of the $\mathrm{T}$ cell mitogens or to alloantigens (see case history). In view of the recent finding that $\mathrm{T}$ cell from patient with $\mathrm{Ne}$ zelof's syndrome respond to mitogens in the presence of exogenous cytokines (24), the influence of exogenous cytokines on the patient's isolated T cells were determined. Normal T cells responded well to PHA in the presence of macrophage factors (Table II). The addition of interleukin 2 (IL-2) enhanced the PHA-induced $T$ cell proliferation. By contrast, the patient's $T$ cells responded minimally to these cytokines in the presence of PHA.

Deficient IL-2 receptor expression by the SCID patient's $T p 40^{-} T$ cells. Isolated $\mathrm{T}$ cells from our patient or from normal controls were activated with PHA-P for $3 \mathrm{~d}$. The T cells were evaluated for the expression of IL-2 receptors using our mAb AT-1 (19). Only $16 \%$ of patient T cells expressed IL-2 receptors, while $81.5 \%$ of control T cells expressed IL-2 receptors (Table III). 5 mo after the successful bone marrow transplant, the patient's $\mathrm{T}$ cells, which now were $\mathrm{Tp} 40^{+}$and of donor origin, expressed IL-2 receptors in a normal fashion.

Activated normal B cells have recently been shown to express IL-2 receptors (19). Before BMT, the patient's B cells were activated with anti- $\mu$ antibodies and BCGF. His activated B cells
Table II. Effect of Cytokines on T Cell Proliferation in SCID Patient

\begin{tabular}{lcc}
\hline & \multicolumn{2}{c}{${ }^{3}$ H-Thymidine (TdR) incorporation $(\mathrm{cpm})$} \\
\cline { 2 - 3 } & Patient & Control \\
\hline Medium & $95 \pm 40$ & $327 \pm 70$ \\
M $\phi$ & $185 \pm 100$ & $207 \pm 50$ \\
rIL-2 & $150 \pm 14$ & $443 \pm 80$ \\
PHA & $1,026 \pm 420$ & $2,650 \pm 260$ \\
PHA + M $\phi S$ & $695 \pm 160$ & $11,997 \pm 380$ \\
PHA + rIL-2 & $1,135 \pm 200$ & $9,144 \pm 70$ \\
PHA + rIL-2 + M $\phi S$ & $658 \pm 30$ & $17,750 \pm 750$
\end{tabular}

$20,000 \mathrm{~T}$ cells were cultured for $3 \mathrm{~d}$ in $0.2 \mathrm{ml}$ medium in the presence of $25 \% \mathrm{M} \phi \mathrm{S}$, rIL-2 $(250 \mathrm{U} / \mathrm{ml})$, and PHA $(10 \mu \mathrm{g} / \mathrm{ml})$ either singly or in combination. $0.5 \mu \mathrm{Ci}$ of tritiated thymidine $\left({ }^{3} \mathrm{H}-\mathrm{TdR}\right)$ was added for the last $6 \mathrm{~h}$ of culture.

expressed IL-2 receptors normally (Table III) as compared with control B cells.

The possibility that $\mathrm{Tp} 40^{-} \mathrm{T}$ cells from a normal individual also did not proliferate and failed to express IL-2 receptors was considered. $\mathrm{Tp} 40^{+}$cells were depleted from $\mathrm{T}$ cell preparations of normal donors using an immune rosette technique. This $T$ cell preparation was found to be $75-95 \% \mathrm{Tp} 40^{-}$by immunofluorescent microscopy. Remaining $\mathrm{Tp} 40^{+}$cells were weakly stained and could not be further depleted by repeated rosetting. These cell preparations were stimulated with PHA, Con A, or PWM. No differences were observed in thymidine uptake of the Tp40$\mathrm{T}$ cell preparations as compared with the unseparated $\mathrm{T}$ cell preparation that contained $>80 \% \mathrm{Tp} 40^{+}$cells (data not shown).

The expression of IL- 2 receptors by mitogen-activated Tp $40^{+}$ and $\mathrm{Tp} 40^{-} \mathrm{T}$ cells was determined by two-color immunofluorescence microscopy using anti IL-2 receptor $\mathrm{mAb} A T-1$. In three separate experiments, both $\mathrm{Tp} 40^{+}$and $\mathrm{Tp} 40^{-} \mathrm{T}$ cells activated by mitogens such as PHA and Con A expressed IL-2 receptors (Table IV). These data indicated that $\mathrm{Tp} 40^{-}$normal $\mathrm{T}$ cells were capable of proliferation in response to $\mathrm{T}$ cell mitogen and of IL-2 receptors expression.

Defective B cell functions of the Tp40-deficient SCID patient before BMT. B cells were isolated from peripheral blood of con-

Table III. Expression of IL-2 Receptors on Activated Lymphocytes

\begin{tabular}{|c|c|c|c|}
\hline & \multicolumn{3}{|c|}{ Lymphocytes expressing IL-2 receptors (\%) } \\
\hline & \multicolumn{2}{|c|}{ Activated $T$ cells } & \multirow{2}{*}{$\frac{\text { Activated B cells }}{\text { Pre-BMT }}$} \\
\hline & Pre-BMT & Post & \\
\hline Patient & 16.1 & 84.6 & 62.2 \\
\hline Control & 81.5 & 76.1 & 57.2 \\
\hline
\end{tabular}

$10^{6} / \mathrm{ml} \mathrm{T}$ cells were activated with PHA-P $(10 \mu \mathrm{g} / \mathrm{ml})$ for $3 \mathrm{~d} .10^{6} / \mathrm{ml}$ non-T cells were activated with rabbit anti-IgM $(10 \mu \mathrm{g} / \mathrm{ml})$ and BCGF for $3 \mathrm{~d}$. Lymphocytes were first incubated with mAb AT-1 (anti-IL-2 receptor) and then counterstained with FITC-goat anti-mouse Ig. After thorough washing, the cells were analyzed with fluorescence microscopy. In the case of non-T cells, rhodamine goat anti-IgM was used to identify B cells. Results were expressed as percentage of cells stained by AT-1. 
Table IV. Expression of IL-2 Receptors by Activated Normal T Cell Subsets

\begin{tabular}{lllll}
\hline & & \multicolumn{3}{l}{ Activated T cells expressing } \\
Mito-2 receptors (\%)
\end{tabular}

$10^{6} / \mathrm{ml} \mathrm{E}^{+}$cells were activated with various mitogens for $3 \mathrm{~d}$. After activation, the cells were stained with rhodamine-conjugated 69.3.4. and counterstained with biotinated AT-1 (anti-IL-2 receptor) and FITCavidin. Numbers of cells expressing IL-2 receptors were counted as percentage of either $\mathrm{Tp} 40^{+}$or $\mathrm{Tp} 40^{-}$cells.

trols and the patient by depletion of $\mathrm{T}$ cells and monocytes using sheep erythrocyte rosette technique and plastic adherence. Rabbit anti-human IgM was used as a first stimulant and a partially purified BCGF preparation (a kind gift of Dr. A. Maizel, M.D. Anderson Hospital and Tumor Institute) was added to stimulate the isolated B cells. B cells from normal donors proliferated vigorously in the presence of these stimulants. The patient's B cells showed proliferation similar to that of normal control B cells (Table V).

Normal B cells developed IL-2 receptors after activation in vitro and became responsive to IL-2 (19). In sharp contrast, while the patient's activated B cells acquired IL-2 receptors in a manner comparable to normal B cells (Table II), these cells did not respond with proliferation to exogenous rIL-2 (Table VI).

In addition to studies of $B$ cell proliferation, differentiation of B cells was studied. Normal B cells differentiated into antibody-secreting cells when stimulated by PWM plus either autologous or allogeneic T cells (Table VII). In an allogeneic system, the patient's $T$ cells, despite their apparent functional deficiency, provided helper activity to normal B cells in the PWM system.

Table V. B Cell Proliferation Induced by Anti-IgM and BCGF in SCID

\begin{tabular}{llcc}
\hline \multirow{2}{*}{$\begin{array}{l}\text { Rabbit } \\
\text { anti-IgM } \\
(10 \mu \mathrm{g} / \mathrm{ml})\end{array}$} & $\begin{array}{l}\text { BCGF } \\
\text { (final dilution) }\end{array}$ & \multicolumn{2}{l}{${ }^{3} \mathrm{H}-\mathrm{TdR}$ incorporation $(\mathrm{cpm})$} \\
\cline { 3 - 4 } & & Control & Patient \\
\hline+ & - & $325 \pm 70$ & $198 \pm 45$ \\
+ & - & $3,799 \pm 320$ & $4,847 \pm 635$ \\
+ & $1: 8$ & $28,881 \pm 200$ & $868 \pm 120$ \\
+ & $1: 8$ & $68,693 \pm 1,300$ & $54,729 \pm 2,800$ \\
+ & $1: 16$ & $42,626 \pm 3,600$ & $44,797 \pm 1,150$ \\
+ & $1: 32$ & $16,827 \pm 1,800$ & $35,123 \pm 280$ \\
+ & $1: 64$ & $19,217 \pm 3,500$ & $26,085 \pm 1,400$ \\
& $1: 128$ & $16,315 \pm 4,300$ & $18,827 \pm 900$ \\
\hline
\end{tabular}

Nonadherent non-T cells were used as B cells at $10^{5}$ cells/microtiter well and cultured for $3 \mathrm{~d}$. Anti-IgM and BCGF were added in appropriate doses at initiation of culture. $0.5 \mu \mathrm{Ci}{ }^{3} \mathrm{H}-\mathrm{TdR}$ was added to culture wells for the last $6 \mathrm{~h}$ of culture.
Table VI. IL-2 Response of Activated B Cells from SCID Patient

\begin{tabular}{lcll}
\hline & \multicolumn{3}{l}{${ }^{3} \mathrm{H}-\mathrm{TdR}$ incorporation $(\mathrm{cpm})$} \\
\cline { 2 - 4 } & & \multicolumn{3}{c}{ Patient } \\
\cline { 2 - 4 } & Control & Pre-BMT & Post-BMT \\
\hline Med & $4,533 \pm 260$ & $1,622 \pm 180$ & $1,150 \pm 80$ \\
rlL-2 $(250 \mathrm{U} / \mathrm{ml})$ & $10,651 \pm 250$ & $1,872 \pm 180$ & $3,576 \pm 110$
\end{tabular}

Isolated B cells were activated with anti-IgM $(10 \mu \mathrm{g} / \mathrm{ml})$ and BCGF $(10 \%)$ for $3 \mathrm{~d}$. After washing, the activated B cells were cultured for an additional $2 \mathrm{~d}$ with either media or $250 \mathrm{U} / \mathrm{ml} \mathrm{rIL-2.} 0.5 \mu \mathrm{Ci}{ }^{3} \mathrm{H}-\mathrm{TdR}$ was added for the last $6 \mathrm{~h}$ of culture. rlL-2 significantly $(P<0.05)$ augmented proliferation of the control $B$ cells and the patient's $B$ cells post BMT.

Although his T cells were nonreactive in MLC, they were able to provide helper cell activity to his parents' isolated B cells in this system (data not shown). In marked contrast, the patient's B lymphocytes did not respond to PWM in the presence of either autologous or allogeneic $\mathrm{T}$ cells.

After normal B cells had been stimulated to proliferate by Staphylococcus aureus or anti-IgM together with BCGF, the activated cells could be driven to differentiate into antibody-secreting cells by addition of conditioned media that contained B cell differentiation factors (19). In this system, our patient's B cells were not inducible to differentiate into antibody-secreting cells (Table VIII).

Restoration of $B$ cell function after BMT. B cell function in this patient was followed serially for several months after BMT. He made specific antibodies and his serum immunoglobulin levels rose to the normal range 6-8 mo after BMT. Cytogenetic

Table VII. Generation of PWM-dependent Plaque-forming Cells (PFC) by T and Non-T Cells in Patient with SCID before and after BMT

\begin{tabular}{|c|c|c|c|c|c|}
\hline \multirow{2}{*}{\multicolumn{2}{|c|}{ Lymphoid cells added }} & \multicolumn{4}{|c|}{$\mathrm{PFC} / 10^{5}$ cells cultured } \\
\hline & & \multicolumn{2}{|l|}{ Pre-BMT } & \multicolumn{2}{|c|}{ Post-BMT } \\
\hline $\mathbf{T}$ & Non- $T$ & Exp. 1 & Exp. 2 & $5 \mathrm{mo}$ & $9 \mathrm{mo}$ \\
\hline Control & - & 90 & 14 & 42 & 1 \\
\hline - & Control & 100 & 52 & 8 & 11 \\
\hline Control & Control & 303 & 360 & 362 & 180 \\
\hline Patient & - & 0 & 7 & 19 & 4 \\
\hline- & Patient & Not done & 6 & 12 & 2 \\
\hline Patient & Patient & 10 & Not done & 33 & 97 \\
\hline Control & Patient & 84 & 25 & 56 & $20^{*}$ \\
\hline Patient & Control & 374 & 355 & 159 & $46^{*}$ \\
\hline
\end{tabular}

Peripheral blood mononuclear cells were depleted of macrophage by plastic adherence and then separated into $T$ and non-T cells by sheep erythrocyte rosettes and Ficoll Hypaque density gradient sedimentation. $5 \times 10^{5}$ cells of each lymphoid cell preparation were cultured in $1 \mathrm{ml}$ of medium in $30 \times 100-\mathrm{mm}$ culture tubes in the presence of $1 \% \mathrm{PWM}$ for $7 \mathrm{~d}$. Reverse plaque assay was performed as described in Methods.

* These low numbers are likely due to allogeneic suppression in the MLC reaction in this experiment. When the control $T$ cells were irradiated with 1,500 rad, 185 PFC were detected. This reversal of suppression was not seen when the patient's $\mathrm{T}$ cells were irradiated, suggesting that a defect of $\mathrm{T}$ cells was still present. 
Table VIII. Effect of Allogeneic T Cell-conditioned Media on Differentiation of $S$. aureus-activated B Cells

\begin{tabular}{llcc}
\hline & & \multicolumn{2}{c}{ PFC/10 cells cultured } \\
\cline { 3 - 4 } Activated B cells & Conditioned media & Pre-BMT & Post-BMT \\
\hline Control & - & 45 & 8 \\
& + & 329 & 137 \\
Patient & - & $<1$ & 2 \\
& + & $<1$ & 83 \\
\hline
\end{tabular}

B cells were isolated after two cycles of depletion of sheep RBC rosettes and cultured with $0.01 \%$ (vol/vol) formalinized $S$. aureus at $10^{6}$ cells $/ \mathrm{ml}$. After $3 \mathrm{~d}$, the cells were thoroughly washed and cultured at $10^{6} \mathrm{cell} / \mathrm{s} / \mathrm{ml}$ for an additional $3 \mathrm{~d}$ in the presence of $20 \%$ conditioned media. Reverse PFC assay was performed as described in Methods.

analysis revealed that B cells in the blood were of host origin 6 mo after BMT. Karyotypes were analyzed from a culture of the patient's B cells stimulated with formalinized $S$. aureus and BCGF, and all were shown to be of male type. Despite the chimeric nature of the lymphoid population, the patient's B cells proliferated to IL-2 after activation (Table VI) 5 mo after transplantation. In addition, host B cells collaborated with both donor $T$ cells and allogeneic $T$ cells and differentiated to Ig-secreting PFC under the influence of PWM (Table VII). Activated B cells were also able to respond to maturation factors to secrete immunoglobulins (Table VIII).

\section{Discussion}

In this report, we have presented evidence that a membrane glycoprotein ( $\mathrm{Tp} 40$ ) was lacking in the $\mathrm{T}$ lymphocytes of a child with SCID syndrome. Recently, membrane defects have been identified in patients with this syndrome as well as with certain other immunodeficiencies. Bare lymphocyte syndrome in which HLA antigens are absent (5-7), and defects of the membrane cytoskeleton have been associated with $\operatorname{SCID}(25,26)$. Deficiencies of leukocyte function antigens have been associated with neutrophil and lymphocyte functional defects (27-32). Deficiency of a membrane glycoprotein gp 115 has been identified in patients with Wiskott-Aldrich syndrome and in patients with certain other $T$ cell deficiency states (33-35). These membrane abnormalities involve primarily structures present in cells of several cell lineages. The marker Tp40 appears to be a peptide specific for a major population of $\mathrm{T}$ lymphocytes (21), although it has been detected occasionally in some blast cells of patients with acute myelogenous leukemia and with chronic myelogenous leukemia in blastic crisis $(36,37)$. Thus, our patient represents a unique instance in which a major $\mathrm{T}$ cell marker deficiency has been identified. Despite our unsuccessful attempt thus far to identify other patients with this defect, further investigation of immunodeficient patients for this molecular deficiency seems warranted.

Although our patient had a demonstrable deficiency of $T$ cell numbers, the circulating $T$ cells had markers of mature $T$ cells including T3, T11, T4 and T8. Despite the presence of these mature $\mathrm{T}$ cell markers, his $\mathrm{T}$ cells did not proliferate well in response to stimulation with mitogens or antigenic stimulation. Attempts to correct the unresponsiveness with exogenous cytokine were not successful. These $T$ cells were also deficient in IL-2 receptor expression. The presence of mature $T$ cell markers on the patient's $T$ cells before transplantation would make the explanation that the absence of $\mathrm{Tp} 40$ is secondary to $T$ cell immaturity unlikely.

One possible explanation for the $\mathrm{T}$ cell defects seen is that the major $\mathrm{T}$ cell subset, $\mathrm{Tp} 40^{+} \mathrm{T}$ cells, was absent and that the remaining minor $\mathrm{Tp} 40^{-} \mathrm{T}$ cells were normally nonfunctional. This possibility, however, was ruled out by the experiments presented herein (Table IV). The reported results of Haynes et al. (21) also indicated that normal $\mathrm{Tp} 40^{-} \mathrm{T}$ cells are capable to proliferate to mitogens, though to a lesser extent than normal $\mathrm{Tp} 40^{+} \mathrm{T}$ cells. Furthermore, Morishima et al. (38) observed that Tp40- $\mathrm{T}$ cell population proliferated to alloantigens in vitro and contained the precursors for cytotoxic $T$ cells. In contrast, the patient's $\mathrm{T}$ cells, which were $\mathrm{Tp} 40^{-}$, were abnormal in proliferation to mitogens and in the ability to express IL-2 receptors. Thus, the coexistence of the absence of Tp40 and abnormalities of the other $T$ cell functions in this patient suggest a cause-effect relationship.

Interestingly, the $\mathrm{T}$ cells from our patient were able to provide helper activities for normal allogeneic B cells to differentiate to Ig-secreting cells. These helper activities are usually provided by $\mathrm{Tp} 40^{+}$cells in normal individuals (21). Thus, the acquisition of $\mathrm{Tp} 40$ and of the functional helper activity for later stages of B cell differentiation were independent events during $T$ cell ontogeny.

In addition to the $T$ cell defects demonstrated, certain $B$ cell defects were also apparent. While the patient's B cells could proliferate in response to anti-IgM and BCGF, these-activated $B$ cells did not differentiate into antibody-secreting cells even in the presence of normal T cells and T cell factors. A related observation was that although his $B$ cells, upon activation, expressed IL-2 receptors as detected by $m A b$, they remained unresponsive to IL-2 stimulation. The dissociation of receptor expression and receptor function with respect to the lymphokine, IL-2, is of considerable interest in view of the recent demonstration that IL-2 receptors express on normal activated B cells and IL-2 can promote B cell proliferation (19, 39-41).

Cytogenetic analyses showed that after bone marrow transplantation, the patient's B cells continued to be of host origin while his $\mathrm{T}$ cells were of donor origin. Despite this chimerism, the patient's serum immunoglobulin levels were restored and he became able to make specific antibodies. It was of additional interest that the persistent host B cells functioned normally in vitro after BMT. They differentiated to Ig-secreting cells in collaboration with normal and donor T cells after PWM stimulation. They were able to respond with proliferation to IL-2 stimulation after activation. This normal response was first observed 5 mo after $T$ cell engraftment. Thus, the host B cells matured under the influence of normal donor $T$ cells in vivo. It appears that Tp40 may play a significant role for early T-B cell interactions, and the absence of $\mathrm{Tp} 40$ does not allow these early events to occur.

In a recent communication, $\mathrm{Tp} 40$ was shown by Lobach et al. (42) to be present in the perithymic mesenchyme at $7 \mathrm{wk}$ of embryogenesis, before the appearance of other $T$ cell surface markers including sheep $\mathrm{RBC}$ receptors, $\mathrm{T} 1, \mathrm{~T} 3, \mathrm{~T} 4$ and $\mathrm{T} 8$. These data indicated that $\mathrm{Tp} 40$ may be expressed on early precursors of $T$ cells and that passage through the epithelial thymus may not be required for its expression. The early appearance of this glycoprotein would add credence to our hypothesis that it plays an important role in the early steps of $\mathrm{T}$ and $\mathrm{B}$ cell devel- 
opment and in T-B cell interactions essential to the normal development of the human immune system.

It has been shown in a murine model that $\mathrm{T}$ cell precursor might affect B cell development (43). Sherr and co-workers (43) found that immature murine B cells from fetal or neonatal donors, when transferred into lethally irradiated adult recipient, would acquire the capacity to reconstitute a normal heterogenous antibody response only if thymus cells were transferred together with them. This suggested that the interaction between thymus cells and fetal B cells were required for the fetal B cells to mature and supported the thesis that early T-B interaction played a crucial role in B cell ontogeny. By analogy, it is possible that the early differentiation antigen $\mathrm{Tp} 40$ in man might be a critical component in such interaction and absence of this protein would result in failure of such interaction and subsequent $B$ cell function.

Tp40 deficiency seen in this patient is a unique finding to date. Studies of two other SCID patients revealed the presence of this antigen. Thus, Tp40 deficiency may only account for the pathogenesis of a small percentage of SCID cases. Despite this, it provided valuable clues to human $T$ cell ontogeny and $T-B$ interaction. Our finding also demonstrated that, in addition to $T$ cell defects measured by conventional $T$ cell function assays, other more subtle defects, such as T-B interactional defects, might be present. In addition, $B$ cell defects observed in our case before transplantation were corrected by allogeneic $\mathrm{T}$ cell graft. These defects were not inherent in the B cell lineage. In the literature, $B$ cell defects were occasionally reported in SCID. The inability to induce SCID B cells to differentiate to Ig-secreting cells in these cases led to the postulate that intrinsic B cell defects were responsible (44). Our findings would suggest extreme caution in such interpretation. Indeed, our findings would support the thesis that $\mathrm{T}$ cell defects are primarily responsible for the pathogenesis of SCID (45).

By immunofluorescence analysis, $T$ cells from the patient's parents and sister expressed Tp40 on cell membranes in quantities similar to that seen in normals. Thus, the results of these analyses did not provide a basis to define the mode of inheritance of this Tp40 deficiency. The lack of family history of early infant deaths and the fact that his siblings are normal argue for the anomaly seen in our patient as a mutational event. Definitive answers as to the genetic basis of the defect must await availability of a DNA probe for the Tp40 gene and analysis of the gene by restriction mapping or sequence analysis.

\section{Acknowledgments}

The excellent clinical care provided this patient by the pediatric interns and residents, fellows and nursing staff of Oklahoma Children's Memorial Hospital is much appreciated. We are especially grateful to Dr. R. Muneer for assistance in cytogenetic analysis and to Craig Wasson for technical assistance.

This work was supported in part by National Institutes of Health grants CA-34546 (to Dr. Fu) and AI-22360, and by March of Dimes Birth Defects Foundation grant 1-789 (to Dr. Good). Dr. Jung is a recipient of a New Investigator Award (R23-3889).

\section{References}

1. Bortin, M. M., and A. A. Rimm. 1977. Severe combined immunodeficiency disease. Characterization of the disease and results of transplantation. JAMA. 237:591-600.

2. Good, R. A., N. Kapoor, and Y. Reisner. 1983. Bone marrow transplantation-an expanding approach to treatment of many diseases. Cell. Immunol. 82:36-54.

3. Polmar, S. H. 1980. Metabolic aspects of immunodeficiency disease. Semin. Hematol. 17:30-43.

4. Hirschhorn, R. 1983. Genetic deficiencies of adenosine deaminase and purine nucleoside. In Primary Immunodeficiency Diseases. Birth Defects: Original Article Series. R. J. Wedgwood, F. S. Rosen, and N. W. Paul, editors. Alan R. Liss Inc., NY. 19:73-81.

5. Touraine, J. L., and H. Bétuel. 1983. The bare lymphocyte syndrome: immunodeficiency resulting from the lack of expression of HLA antigens. In Primary Immunodeficiency Diseases. Birth Defects: Original Article Series. R. J. Wedgwood, F. S. Rosen, and N. W. Paul, editors. Alan R. Liss Inc., NY. 19:83-85.

6. Lisowska-Grospierre, B., A. Durandy, J. L. Viselizien, A. Fischer, and C. Griscelli. 1983. Combined immunodeficiency with defective expression of HLA: modulation of an abnormal HLA synthesis and functional studies. In Primary Immunodeficiency Diseases. Birth Defects: Original Article Series. R. J. Wedgwood, F. S. Rosen, and N. W. Paul, editors. Alan R. Liss Inc., NY. 19:87-91.

7. Zegers, B. J. M., D. J. Heijner, J. J. Roord, W. Kuis, R. K. B. Schuurman, J. W. Stoop, and R. E. Ballieux. 1983. Defective expression of mononuclear cell membrane HLA antigens associated with combined immunodeficiency: impaired cellular interactions. In Primary Immunodeficiency Diseases. Birth Defects: Original Article Series. R. J. Wedgwood, F. S. Rosen, and N. W. Paul, editors. Alan R. Liss Inc., NY. 19: 93-96.

8. Good, R. A., R. D. A. Peterson, D. Y. Perey, J. Finsted, and M. D. Cooper. 1968. The immunological deficiency disease of man: consideration of some questions asked by these patients with an attempt at classification. In Immunologic Deficiency Diseases in Man. Birth Defects: Original Articles Series. D. Bergsma and R. A. Good, editors. Williams and Wilkins Co., Baltimore. 4:17-39.

9. Pyke, K. W., H. M. Dosch, M. M. Ipp, and E. W. Gelfand. 1975. Demonstration of an intrathymic defect in a case of severe combined immunodeficiency disease. $N$. Engl. J. Med. 293:424-428.

10. Pahwa, R. N., S. G. Pahwa, and R. A. Good. 1978. T lymphocyte differentiation in severe combined immunodeficiency: defects of the thymus. Clin. Immunol. Immunopathol. 11:437-444.

11. Businco, L., F. Pandolfi, P. Rossi, D. Del Principi, M. Fiorilli, I. Quinti, and F. Aiuti. 1981. Selective defect of a T helper subpopulation in severe combined immunodeficiency. J. Clin. Immunol. 1:125-130.

12. Tsuchiya, S., M. Minegishi, M. Imaizumi, S. Nakai, S. Tamura, T. Konno, and K. Tada. 1983. Selective defect of OKT4 $4^{+} \mathrm{T}$ lymphocytes in severe immunodeficiency. J. Pediatr. 103:588-591.

13. Duse, M., R. Maccario, L. Nespoli, A. Plebani, and A. G. Ugazio. 1984. Selective deficiency of OKT4 $4^{+}$lymphocytes in a child with combined immunodeficiency. In Primary Immunodeficiency Diseases. Birth Defects: Original Articles Series. R. J. Wedgwood, F. S. Rosen, and N. W. Paul, editors. Alan R. Liss Inc., NY. 19:105-106.

14. Bernard, A., L. Boumsell, and C. Hill. 1984. Joint report of the First International Workshop on Human Leukocyte Differentiation Antigens by the investigators of participating laboratories. In Leukocyte Typing. A. Bernard, L. Boumsell, J. Dausset, C. Milstein, and S. F. Schlossman, editors. Springer-Verlag, New York. 9-142.

15. Hara, T., and S. M. Fu. 1985. Human T cell activation. I. Monocyte-independent activation and proliferation induced by anti- $\mathrm{T}_{3}$ monoclonal antibodies in the presence of tumor promoter 12-O-tetradecanoyl phorbol-13-acetate. J. Exp. Med. 161:641-656.

16. Chiorrazi, N., S. M. Fu, and H. G. Kunkel. 1980. Stimulation of human B lymphocytes by antibodies to IgM and IgG: functional evidence for the expression of IgG on B lymphocyte surface membrane. Clin. Immunol. Immunopathol. 15:301-313.

17. Yen, S. H., F. Gaskin, and S. M. Fu. 1983. Neurofibrillary tangles in senile dementia of the Alzheimer type share an antigenic determinant with intermediate filaments of the vimentin class. Am. J. Pathol. 113: 373-381.

18. Jung, L. K. L., and S. M. Fu. 1984. Selective inhibition of growth factor dependent human B cell proliferation by monoclonal antibody 
AB1 to antigen expressed by activated B cell. J. Exp. Med. 160:19191924.

19. Jung, L. K. L., T. Hara, and S. M. Fu. 1984. Detection and functional studies of p60-65 (Tac antigen) on activated human B cells. J. Exp. Med. 160:1597-1602.

20. Finelt, M., and M. K. Hoffmann. 1979. A human monocyte function test: release of B cell differentiation factor (BDF). Clin. Immunol. Immunopathol. 12:281-288.

21. Haynes, B. F., G. S. Eisenbarth, and A. S. Fauci. 1979. Human lymphocyte antigen: production of a monoclonal antibody that defines functional thymus-derived lymphocyte subsets. Proc. Natl. Acad. Sci. USA. 76:5829-5833.

22. Sutherland, D. R., C. E. Rudd, and M. F. Greaves. 1984. Isolation and characterization of a human $\mathrm{T}$ lymphocyte-associated glycoprotein (gp40). J. Immunol. 133:327-333.

23. Hara, T., and S. M. Fu. 1985. Phosphorylation of $\alpha, \beta$ subunits of $180 / 100 \mathrm{Kd}$ polypeptides (LFA-1) and related antigens. In Leukocyte Typing II. E. L. Reinherz, B. F. Haynes, L. M. Nadler, and I. D. Bernstein, editors. Springer-Verlag New York Inc., New York. In press. 77-84.

24. Flomenberg, N., K. Welte, R. Mertelsman, N. Kernan, N. Ciobanu, S. Venuta, S. Feldman, G. Kruger, D. Kirkpatrick, B. Dupont, and R. O'Reilly. 1983. Immunologic effect of interleukin 2 in primary immunodeficiency diseases. J. Immunol. 130:2644-2650.

25. Gelfand, E. W., J. M. Oliver, R. K. Schuurman, D. S. Matheson, and H. M. Dosch. 1979. Abnormal lymphocyte capping in a patient with severe immunodeficiency disease. N. Engl. J. Med. 301:1245-1249.

26. Gehrz, R. C., J. J. McAuliffe, K. M. Linner, and J. H. Kersey. 1980. Defective membrane function in a patient with severe combined immunodeficiency disease. Clin. Exp. Immunol. 39:344-348.

27. Beatty, P. G., H. D. Ochs, J. M. Harland, T. H. Price, H. Rosen, R. F. Taylor, J. A. Hansen, and S. Klebanoff. 1984. Absence of a monoclonal antibody-defined protein complex in a boy with abnormal leukocyte function. Lancet. I:535-537.

28. Bowen, T. J., H. D. Ochs, L. C. Altman, T. H. Price, D. E. Van Epps, D. L. Brautigan, R. E. Rosin, W. D. Perkins, B. M. Babior, S. J. Klebanoff, and R. J. Wedgwood. 1982. Severe recurrent bacterial infections associated with defective'adherence and chemotaxis in two patients with neutrophils deficient in a cell-associated glycoprotein. J. Pediatr. 101:932-940.

29. Crowley, C. A., J. T. Curnutte, R. E. Rosin, J. André-Schwartz, J. I. Gallin, M. Klempner, R. Snyderman, F. S. Southwick, T. P. Stossel, and B. M. Babior. 1980. An inherited abnormality of neutrophil adhesion. Its genetic transmission and its association with a missing protein. $N$. Engl. J. Med. 302:1163-1168.

30. Kobayashi, K., K. Fujita, F. Okino, and T. Kajii. 1984. An abnormality of neutrophil adhesion: autosomal recessive inheritance associated with missing neutrophil glycoprotein. Pediatrics. 73:606-610.

31. Arnaout, M. A., J. Pitt, H. J. Cohen, J. Melamed, F. S. Rosen, and H. R. Colten. 1982. Deficiency of a granulocyte membrane glycoprotein (gp150) in a boy with recurrent bacterial infection. N. Engl. J. Med. 306:693-699.
32. Miedema, F., P. A. T. Tetteroo, F. G. Terpstra, G. Keizer, M. Roos, R. S. Weening, C. M. R. Weemaes, D. Roos, and C. J. M. Melief. 1985. Immunologic studies with LFA-1 and Mo-1 deficient lymphocytes from a patient with recurrent bacterial infections. J. Immunol. 134:30753081.

33. Parkman, R., E. Remold-O'Donnell, D. M. Kenney, S. Perrine, and F. S. Rosen. 1981. Surface protein abnormalities in lymphocytes and platelets from patients with Wiskott-Aldrich syndrome. Lancet. II: 1387-1389.

34. Remold-O'Donnell, E., D. M. Kenney, R. Parkman, L. Cairns, B. Savage, and F. S. Rosen. 1984. Characterization of a human lymphocyte surface sialoglycoprotein that is defective in Wiskott-Aldrich syndrome. J. Exp. Med. 159:1705-1723.

35. Parkman, R., E. Remold-O'Donnell, L. Cairn, J. M. Rappeport, M. Cowan, A. Ammann, D. Kenney, N. Potter, and F. S. Rosen. 1984. Immune abnormalities in patients lacking a lymphocyte surface glycoprotein. Clin. Immunol. Immunopathol. 33:363-370.

36. Haynes, B. F. 1981. Human T lymphocyte antigens as defined by monoclonal antibodies. Immunol. Rev. 57:127-161.

37. Vodinelich, L., W. Tax, Y. Bai, S. Pegram, P. Capel, and M. F. Greaves. 1983. A monoclonal antibody (WT1) for detecting leukemias of T cell precursors. Blood. 62:1108-1113.

38. Morishima, Y., M. Kobayashi, S. Y. Yang, N. H. Collins, M. K. Hoffmann, and B. Dupont. 1982. Functionally different T lymphocyte subpopulations determined by their sensitivity to complement-dependent cell lysis with the monoclonal antibody 4A. J. Immunol. 129:1091-1098.

39. Tsudo, M., T. Uchiyama, and H. Uchimo. 1984. Expression of Tac antigen on activated normal human B cells. J. Exp. Med. 160:612617.

40. Zubler, R. H., J. W. Lowenthal, F. Erard, N. Hashimoto, R. Devos, and H. R. MacDonald. 1984. Activated B cells express receptors to and proliferate in response to pure interleukin 2. J. Exp. Med. 160: 1170-1183.

41. Waldmann, T. A., C. K. Goldman, R. J. Robb, J. M. Depper, W. J. Leonard, S. O. Sharrow, K. F. Bongiovanni, S. J. Korsmeyer, and W. C. Greene. 1984. Expression of interleukin 2 receptors on activated human B cells. J. Exp. Med. 160:1450-1466.

42. Lobach, D. F., L. L. Hensley, W. Ho, and B. F. Haynes. 1985. Human $\mathrm{T}$ cell antigen expression during the early stages of fetal thymic maturation. J. Immunol. 135:1752-1759.

43. Sherr, D. H., M. R. Szewczuk, and G. W. Siskind. 1978. Ontogeny of B lymphocyte Function V. Thymus cell involvement in the functional maturation of B lymphocytes from fetal mice transferred into adult irradiated hosts. J. Exp. Med. 147:196-206.

44. Pahwa, S. G., R. N. Pahwa, and R. A. Good. 1980. Heterogeneity of $B$ lymphocyte differentiation in severe combined immunodeficiency disease. J. Clin. Invest. 66:543-550.

45. Dosch, H. M., J. W. W. Lee, E. W. Gelfand, and J. A. Falk. 1978. Severe combined immunodeficiency disease: a model of $T$ cell dysfunction. Clin. Exp. Immunol. 34:260-267. 